\title{
Role of Platelets in Cholesteryl Ester Formation by U-937 Cells
}

\author{
Michael E. Mendelsohn* and Joseph Loscalzo** \\ Cardiology Division* and Division of Vascular Medicine, ${ }^{\ddagger}$ Department of Medicine, Brigham \& Women's Hospital and Harvard \\ Medical School, Boston, Massachusetts 02115
}

\begin{abstract}
The conversion of tissue macrophages into cholesteryl esterrich foam cells is a crucial early event in atherogenesis. We studied the platelet as a potential source of cholesterol for esterification by macrophages because $(a)$ platelets are rich in free cholesterol, (b) they adhere to macrophages early in atherogenesis, and $(c)$ vascular injury can induce foam cell formation in the absence of hyperlipoproteinemia. We found that washed, activated human platelets from normocholesterolemic donors stimulated cholesteryl ester formation by the human monocyte-derived cell, U-937. Platelet cholesterol, released from platelets activated with calf skin collagen, was approximately equipotent at donating cholesterol to U-937 cells for esterification as normal human low density lipoprotein cholesterol. The stimulation of cholesteryl ester formation by activated human platelets demonstrated both concentration and time dependence. When hypercholesterolemic donors were studied, it was found that increasing plasma levels of cholesterol correlated directly with the ability of these hypercholesterolemic platelets to support cholesteryl ester synthesis by U-937 cells. Cholesterol-donating activity was also found in a 1,000-g supernatants of activated platelets. These observations point to a new and potentially important role for platelets in atherogenesis and suggest a mechanism for foam cell formation in the absence of marked hypercholesterolemia.
\end{abstract}

\section{Introduction}

Among the early important events in atherogenesis is the conversion of macrophages into foam cells. The source and state of the cholesterol utilized by macrophages in the synthesis of cholesteryl ester $(\mathrm{CE})^{1}$ during foam cell formation has been the subject of great interest in recent years. The studies of Brown, Goldstein, and colleagues (1) describing the presence of a high affinity receptor for LDL on human skin fibroblasts led to an examination of macrophages for the presence of such receptors. While murine macrophages were not found to express classic LDL receptors, nor to synthesize CE in the presence of

This work was published in part in abstract form (1985. Clin. Res. 34:326a).

Address correspondence to Dr. Loscalzo, Brigham \& Women's Hospital, 75 Francis St., Boston, MA 02115.

Received for publication 29 December 1986 and in revised form 4 August 1987.

1. Abbreviations used in this paper: CE, cholesteryl ester; FAFBSA, fatty acid-free BSA; LDH, lactate dehydrogenase.

J. Clin. Invest.

(c) The American Society for Clinical Investigation, Inc. 0021-9738/88/01/0062/07 $\$ 2.00$

Volume 81, January 1988, 62-68
LDL (2), human monocyte-derived macrophages did have these receptors in abundance (3-5); however, because the classic pathway is efficiently regulated in human macrophages, net CE accumulation did not appear to be mediated simply by this classic LDL receptor mechanism.

So-called scavenger receptors have been demonstrated on human monocyte-derived macrophages, as well. These receptors recognize chemically modified LDL (acetylated or malondialdehyde modified), and intracellular CE accumulation has been shown to occur by this alternate pathway $(2,6)$. While evidence has appeared for chemically modified LDL (7-10) and native, unmodified LDL (11) itself as possible contributors to foam cell formation, to date neither the physiologic lipoprotein substrate nor the specific type or source of in vivo modification necessary for receptor recognition has been identified. Recently, an apoprotein E receptor (12) that mediates cholesterol uptake by human monocyte-derived macrophages from VLDL has veen identified that behaves in a manner biochemically distinct from the LDL receptor and the scavenger receptor, and that appears to support CE formation in these mononuclear cells. Recent studies suggest that this receptor is immunologically similar or identical to the native LDL receptor $(13,14)$. The precise nature and pathophysiologic importance of this pathway, however, has yet to be determined.

The difficulty in identifying the mechanism by which human macrophages are provided with cholesterol for esterification is further complicated by the observation that injury of the endovascular surface is associated with the induction of atheroma formation even in the absence of hypercholesterolemia or dyslipoproteinemia of any sort (15-22). This suggests that other elements in the complex cascade of cellular and biochemical events leading to atheroma may be important for foam cell development.

Platelets play an important role in the generalized response to injury. They not only interact with endothelium in the initial phases of vascular injury (23) and adhere to deendothelialized vascular tissue, secreting mitogen to stimulate smooth muscle cell and fibroblast proliferation (24), but also appear to interact directly with macrophages, coating them at sites of injury $(25,26)$. In addition, recent morphologic evidence of the platelet's ability to induce $\mathrm{CE}$ accumulation within cultured rat smooth muscle cells has appeared (27).

Platelets are rich in unesterified cholesterol (28) and because (a) platelets interact directly with macrophages early in atherogenesis, $(b)$ inhibiting platelet function or lowering platelet number inhibits atheroma formation in animal models (29), and (c) unesterified platelet cholesterol is released on platelet activation (30), we studied the activated human platelet as a source of cholesterol for esterification by macrophages in foam cell evolution. We used the human monocytelike cell line, U-937 $(31,32)$, and platelets from normolipidemic or hypercholesterolemic individuals. By incubating these 
monocytes in culture with activated human platelets in the absence of any other source of cholesterol, we have shown that activated platelets are potent donors of cholesterol for esterification by U-937 cells.

\section{Methods}

Materials. $\left[1-{ }^{14} \mathrm{C}\right]$ Oleic acid and $\left[1,2-{ }^{3} \mathrm{H}\right]$ cholesteryl oleate were obtained from New England Nuclear, Boston, MA. $\left[2-{ }^{14} \mathrm{C}\right]$ Acetate was purchased from Amersham Corp., Arlington Heights, IL. Cholesteryl oleate was purchased from Nu Chek Prep, Inc., Elysian, MN. Cell culture materials, including DME, PBS, FCS, penicillin, and streptomycin were all purchased from Gibco, Grand Island, NY. Fatty acidfree BSA (FAFBSA), sodium taurocholate, and $p$-hydroxyphenylacetic acid (HPAA) were obtained from Sigma Chemical Co., St. Louis, MO. Calf skin collagen was purchased from Cooper Biomedical, Inc., Malvern, PA. Plastic culture dishes ( $35 \mathrm{~mm}$ ) were purchased from Falcon Labware, Becton-Dickinson \& Co., Oxnard, CA. Horseradish peroxidase and cholesterol oxidase were obtained from Calbiochem-Behring Corp., San Diego, CA. CE hydrolase from Pseudomonas aeruginosa was purchased from Boehringer Mannheim Biochemicals, Indianapolis, IN. TLC plates were obtained from The Anspec Co., Inc., Ann Arbor, MI. All other chemicals used were reagent grade or better.

Preparation of U-937 monolayers. U-937 cells were generously donated by Dr. Michael Gimbrone and Dr. Frank Sacks (Harvard Medical School) and maintained in stock culture in DME with 10\% FCS in $5 \% \mathrm{CO}_{2}$ at $37^{\circ} \mathrm{C}$. Before each experiment, cells were preincubated in DME with $0.2 \%$ FAFBSA, $100 \mathrm{U} / \mathrm{ml}$ penicillin, and $100 \mu \mathrm{g} / \mathrm{ml}$ streptomycin (assay buffer) for 19-24 h. At the start of each experiment, aliquots of this cell suspension containing $1 \times 10^{6}$ cells were dispensed into plastic culture dish wells, centrifuged at $160 \mathrm{~g}$ for $10 \mathrm{~min}$, and the supernatant removed by gentle suction.

Collection and preparation of human platelets. Venous blood was drawn into $15.6 \mathrm{mM}$ citric acid, $89.4 \mathrm{mM}$ trisodium citrate, $16.1 \mathrm{mM}$ $\mathrm{NaH}_{2} \mathrm{PO}_{4}$, and $142 \mathrm{mM}$ dextrose (CPD) (nine parts blood to one part CPD). Platelet-rich plasma was prepared by centrifugation at $120 \mathrm{~g}$ for $10 \mathrm{~min}$ at $22^{\circ} \mathrm{C}$. The platelet-rich plasma was then placed in polypropylene tubes, centrifuged at $800 \mathrm{~g}$ for $10 \mathrm{~min}$ at $22^{\circ} \mathrm{C}$, and the supernatant removed. The platelet pellet was resuspended in $10 \mathrm{mM}$ sodium citrate, $0.15 \mathrm{M} \mathrm{NaCl}, 1 \mathrm{mM}$ EDTA, and $1 \%$ dextrose (platelet washing buffer) by gentle, repeated suction with a polypropylene transfer pipette. The washing procedure was repeated twice and the final platelet pellet resuspended in assay buffer. An aliquot was removed from each platelet preparation for determination of platelet concentration using a counter (model F; Coulter Electronics Inc., Hialeah, FL) equipped with a $50-\mu \mathrm{m}$ aperture tube (Coulter Electronics Inc.). Platelets were maintained at $22^{\circ} \mathrm{C}$ for up to $1 \mathrm{~h}$ before use. Platelet preparations contained <1:1,000 contamination by white blood cells in each instance.

Platelet releasate preparation. Platelet releasates were prepared by incubating washed platelets with $0.1 \mathrm{mg} / \mathrm{ml}$ of calfskin collagen for either $5 \mathrm{~min}$ or $60-90 \mathrm{~min}$ at $37^{\circ} \mathrm{C}$. The incubation mixture was then centrifuged at $1,000 \mathrm{~g}$ for $10 \mathrm{~min}$ and the supernatant saved for use in experiments with $\mathrm{U}-937$ cells.

Lipoprotein preparations. Human LDL (density, 1.020-1.063 $\mathrm{g} / \mathrm{ml}$ ) and HDL (density, $1.070-1.21 \mathrm{~g} / \mathrm{ml}$ ) were isolated from the plasma of normolipidemic, fasting volunteers by differential ultracentrifugation as described previously (33). LDL was acetylated by repeated additions of acetic anhydride (6). $\beta$-VLDL was isolated from the plasma of rabbits fed a semi-synthetic cholesterol diet for 2-6 mo. The lipoprotein fraction with a density $<1.006$ was prepared by ultracentrifugation and subfractionated by cumulative rate density ultracentrifugation.

$C E$ assay. A modified version of the assay of Brown and colleagues (34) was used. Wells containing $1 \times 10^{6} \mathrm{U}-937$ cells were incubated with a particular lipoprotein class, unactivated platelets, or platelet releasate in a final volume of $1.0 \mathrm{ml}$. Activation of platelets was stimu- lated by addition of calfskin collagen to wells containing U937 cells and unactivated platelets. Each assay was performed in triplicate. To each well was added $0.5 \mu \mathrm{Ci}$ of $\left[1-{ }^{14} \mathrm{C}\right]$ oleate complexed to albumin (35) and the wells were then incubated for $19-24 \mathrm{~h}$ at $37^{\circ} \mathrm{C}$. At the end of the incubation period, cells were harvested by two in situ washings with PBS containing $0.2 \% \mathrm{wt} / \mathrm{vol} \mathrm{BSA}$, followed by two washings with PBS alone, all performed at $4^{\circ} \mathrm{C}$. Cellular lipids were then extracted for $60 \mathrm{~min}$ in $1.0 \mathrm{ml}$ of hexane-isopropanol (3:2 vol/vol) (33), to which was added $\left[1,2 \cdot{ }^{3} \mathrm{H}\right]$ cholesteryl oleate to monitor recovery. The solutions were transferred to $12 \times 75-\mathrm{mm}$ glass tubes and the solvent evaporated in an evacuated chamber (Speed Vac; Savant Instruments, Hicksville, NY) or under a ventilated hood. Lipids were dissolved in 50 $\boldsymbol{\mu l}$ of hexane containing $2 \mathrm{mg} / \mathrm{ml}$ cholesteryl oleate and applied to 20 $\times 20$-cm Whatman LK6DF silica gel TLC plates. The plates were developed with petroleum ether/diethyl ether/acetic acid (80:20:1) and the $C E$ fraction visualized with iodine vapor. The $C E$ spot was scraped into scintillation vials, Bioscint (National Diagnostics, Somerville, NJ) was added, and double channel counting was performed in a analytic liquid scintillation counter (Tracor; TM Analytic, Inc., Elk Grove Village, IL).

Counts per minute in each well were corrected for counting efficiency and expressed in two forms: $(i)$ as picomoles of CE formed per milligram of U937 cell protein per hour of incubation (the total CE formed per well), and (ii) picomoles of CE formed per milligram of U937 cell protein per hour normalized to the total quantity of cholesterol added to the assay well (total CE formed per microgram cholesterol from the substrate provided). This latter value was calculated to allow comparison among wells containing different sources of cholesterol (e.g., LDL versus human platelets). Quenching was assessed by comparing counts between duplicate tubes containing a known aliquot of $\left[1-{ }^{14} \mathrm{C}\right]$ oleate and tubes containing this same aliquot plus scrapings from blank TLC lanes developed and recovered in a manner identical to that detailed above. Quenching of the radiolabeled CE samples prepared under these conditions in Bioscint (National Diagnostics) was $<3 \%$.

Control studies using $4 \mu \mathrm{Ci}$ per well of $\left[1-{ }^{14} \mathrm{C}\right]$ acetate (specific activity, $56 \mathrm{mCi} / \mathrm{mmol}$ ), alone or in the presence of platelet releasate, were performed using volumes and assay conditions identical to those described for $\left[1-{ }^{14} \mathrm{C}\right]$ oleate, but without albumin complexation.

CE mass measurements were also made in hexane-isopropanol extracts (36) of wells using the fluorimetric assay of Heider and Boyett (37) and Gamble and colleagues (38).

Analytic methods. Platelet lipids were extracted with hexane-isopropanol (36). Total cholesterol was determined by the methods of Rudel and Morris (39) or of Heider and Boyett (37) and Gamble and colleagues (38). Protein concentration was determined by the method of Lowry and colleagues (40). Total cellular DNA content was determined by the method of Kapuscinski and Skoczylas (41). LDH was assayed by a modification of the method of Wacker and colleagues (42).

\section{Results}

Effect of lipoproteins on $C E$ synthesis by $U-937$ cells. The effects of various lipoproteins and free cholesterol on CE synthesis by U-937 cells are listed in Table I. Each $\beta$-VLDL or LDL value represents the mean \pm standard deviation of six to ten experiments done in triplicate. CE formation is given as picomoles of cholesteryl oleate formed per milligram of U-937 cell protein per hour and as picomoles CE formed per milligram protein per hour per microgram of cholesterol added. Clearly, rabbit $\beta$-VLDL is the most potent cholesterol donor in this system. Human LDL stimulates approximately one-third the CE synthesis as that by $\beta$-VLDL. Importantly, human HDL and human acetyl-LDL, as well as free cholesterol, failed to induce $\mathrm{CE}$ formation to any significant degree. 
Table I. Effect of Different Cholesterol Sources on CE Formation by $U-937$ Cells

\begin{tabular}{lcl}
\hline Cholesterol source & Total CE formed & $\begin{array}{l}\text { Total CE formed per } \\
\text { microgram cholesterol } \\
\text { added }\end{array}$ \\
\hline & pmol CE/mg protein/h & $\begin{array}{l}\text { pmol CE/mg protein/h/ug } \\
\text { cholesterol added }\end{array}$ \\
Rabbit $\beta$-VLDL* & $1,998 \pm 514$ & $5.23 \pm 1.77$ \\
Human LDL* & $627 \pm 355$ & $1.64 \pm 1.72$ \\
Human HDL & 27 & 0.17 \\
Hman acetyl-LDL & 9 & 0.01 \\
Cholesterol in EtOH & 18 & 0.04 \\
\hline
\end{tabular}

Each assay well contained $60-100 \mu \mathrm{g}$ of lipoprotein cholesterol, $1 \times 10^{6}$ cells, and $0.5 \mu \mathrm{Ci}$ of $\left[{ }^{14} \mathrm{C}\right]$ oleate complexed to albumin, all in DME with $0.2 \%$ FAFBSA. Incubations were performed at $37^{\circ} \mathrm{C}$ for $20 \mathrm{~h}$. Recovery of CE was assessed to be $53 \pm 16 \%$ as measured by a tritiated CE standard.

* Each value represents the average \pm standard deviation of six to ten experiments performed in triplicate.

Stimulation of CE formation by $U-937$ cells with activated human platelets. The effect of resting and activated human platelets on CE synthesis by U-937 cells is shown in Table II. Washed, unactivated platelets failed to stimulate ester synthesis to any appreciable extent. In contrast, washed platelets activated with calfskin collagen $(0.1 \mathrm{mg} / \mathrm{ml})$ were a potent source of cholesterol and stimuli for its esterification by U-937 cells.

Mass measurements of CE by the U-937 cells are shown in Table III and corroborate the implications of the rate experiments. These data show that the increases seen in labeled CE are a result of net accumulation and not of increased turnover and labeling of the intracellular pool of cholesterol without a net increase in mass.

Table II. Effect of Platelet Activation on CE Formation by $U-937$ Cells

\begin{tabular}{lll}
\hline Cholesterol source & Total CE formed & $\begin{array}{l}\text { Total CE formed } \\
\text { per microgram } \\
\text { cholesterol added }\end{array}$ \\
\hline & pmol CE/mg protein/h & $\begin{array}{l}\text { pmol CE/mg/h/ug } \\
\text { cholesterol added }\end{array}$ \\
$\begin{array}{l}\text { Unactivated platelets } \\
(n=4)\end{array}$ & $10.8 \pm 8.0$ & $0.23 \pm 0.20$ \\
$\begin{array}{c}\text { Collagen-activated platelets } \\
(n=14)\end{array}$ & $72.0 \pm 43.4$ & $1.35 \pm 0.72$ \\
Collagen releasate $(n=4)$ & $68.2 \pm 13.4$ & $1.23 \pm 0.35$ \\
\hline
\end{tabular}

Each value represents the average of $n$ experiments performed in triplicate. Each assay well contained 12-37 $\mu \mathrm{g}$ of whole-platelet cholesterol, $0.7-3.4 \times 10^{8}$ platelets $/ \mathrm{ml}, 1.0 \times 10^{6} \mathrm{U}-937 \mathrm{cells} / \mathrm{ml}$, and $0.5 \mu \mathrm{Ci}$ of $\left[{ }^{14} \mathrm{C}\right]$ oleate complexed to albumin, all in DME with $0.2 \%$ FAFBSA. Recovery of CE was $53 \pm 16 \%$ as measured by a tritiated CE standard. U-937 cell protein was measured by the method of Lowry and colleagues (40) in wells without platelets or was derived from the DNA content of U-937 cells in wells with platelets (assuming a value of $4.2 \mathrm{pg}$ protein $/ \mathrm{pg}$ DNA) as measured by the method of Kapuscinski and Skoczylas (41).
Table III. Effect of Different Cholesterol Sources on CE Mass in U937 Cells

\begin{tabular}{ll}
\hline Cholesterol source & Total CE content \\
\hline & $\mu g / m g$ protein \\
LDL & 37.0 \\
Unactivated platelets & 8.3 \\
Collagen-activated platelets & 36.5 \\
Collagen releasate & 43.0 \\
\hline
\end{tabular}

Each value represents the average of two experiments performed in triplicate. Each assay well contained either $100 \mu \mathrm{g}$ of LDL cholesterol or $10 \mu \mathrm{g}$ of platelet or releasate cholesterol and $1 \times 10^{6} \mathrm{U} 937$ cells in DME with $0.2 \%$ FAFBSA. Incubations were performed at $37^{\circ} \mathrm{C}$ for $20 \mathrm{~h}$. U937 cell protein was measured by the method of Lowry and colleagues (40) in wells without platelets or was derived from the DNA content of U937 cells in wells with platelets (assuming a value of $4.2 \mathrm{pg}$ protein/pg DNA) as measured by the method of Kapuscinski and Skoczylas (41).

Fig. 1 depicts the concentration dependence of CE synthesis by U-937 cells in response to collagen-activated platelets. Washed, collagen-activated platelets led to increasing amounts of total CE formation when increasing quantities of platelet cholesterol were present in assay wells. The phenomenon appears to saturate, as $\sim 30 \mu \mathrm{g} / \mathrm{ml}$ of platelet cholesterol are presented to the U937 cells.

Table IV depicts three time points in the incubation of U-937 cells with platelet cholesterol to stimulate CE synthesis. The total CE formed increases in a linear fashion over time, with comparable rates of CE formation at each of the time points.

Effect of activated platelet releasate on CE formation by $U-937$ cells. The 1,000-g supernatant of human platelets activated with calfskin collagen $(0.1 \mathrm{mg} / \mathrm{ml})$ was also tested as a source of cholesterol for esterification by U-937 cells. Table II shows that the activity of this supernatant (releasate) in stimulating $C E$ formation is quite significant, being approximately

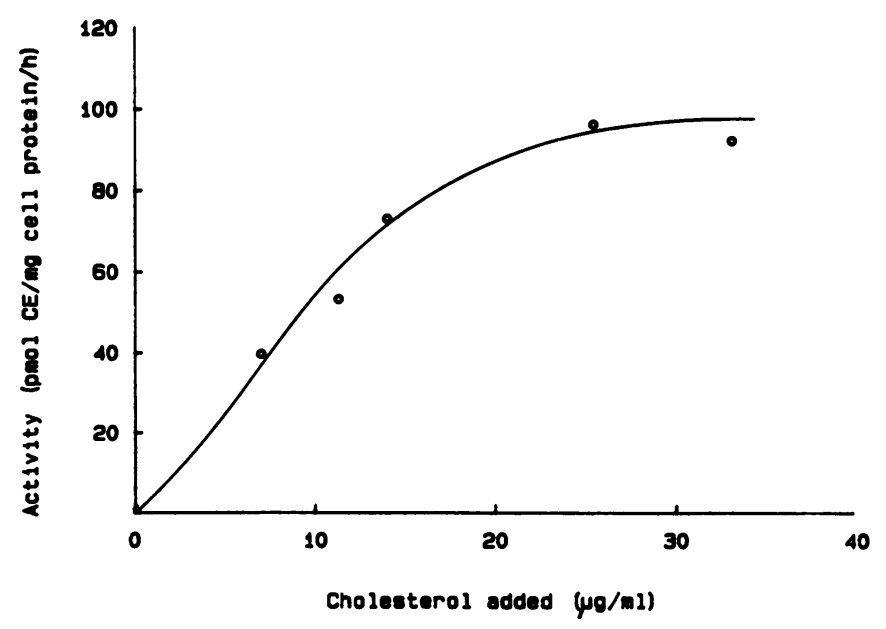

Figure 1. CE synthesis as a function of increasing amounts of platelet cholesterol. Platelets were activated and cholesterol synthetic activity of the U-937 cells was measured as described in Methods. 
Table IV. Time Course of CE Formation by U-937 Cells Stimulated by Activated Platelets

\begin{tabular}{lll}
\hline Time & Total CE formed & $\begin{array}{l}\text { Total CE formed per microgram } \\
\text { cholesterol added }\end{array}$ \\
\hline$h$ & pmol CE/mg protein & pmol CE/mg/h/ug cholesterol added \\
3 & 336 & 1.20 \\
6 & 660 & 1.18 \\
$21.6 \pm 1.6$ & $1,730 \pm 922$ & $1.35 \pm 0.72$ \\
\hline
\end{tabular}

Each point represents the average of 1 to 14 experiments performed in triplicate. 11-33 $\mu \mathrm{g}$ of cholesterol was added per well. For further details see Methods and the legends to Tables I and II.

as potent per microgram of cholesterol as the activated platelets from which it came. The concentration dependence between collagen releasate cholesterol and CE formation is shown in Fig. 2. The data show that the formation of $C E$ is similar to that stimulated by activated whole platelets as illustrated in Fig. 1, with similar saturability in the $30-\mu \mathrm{g} / \mathrm{ml}$ range.

Control studies using lovastatin at a final concentration of $10 \mu \mathrm{M}$ were performed both with activated platelets and with platelet releasate prepared as described above. No inhibition of CE synthesis was noted either with activated platelets or with releasate, suggesting that $\mathrm{CE}$ accumulation was not due to intracellular cholesterol synthesis. A further control study was performed using $\left[{ }^{14} \mathrm{C}\right]$ acetate as a potential substrate for cholesterol synthesis. No cholesterol synthesis was detected using this technique, further substantiating that $\mathrm{CE}$ accumulation was due to a process other than de novo cellular synthesis.

In addition, control studies using only U-937 cells and calf skin collagen (without platelets) failed to stimulate any $\mathrm{CE}$ synthesis. Given that platelets were the only source of cholesterol in this lipoprotein-free system, it may be concluded that the activated platelets themselves provided cholesterol to U-937 cells for esterification with oleate.

Further control studies were performed to address whether the active releasate material was derived from nonspecific

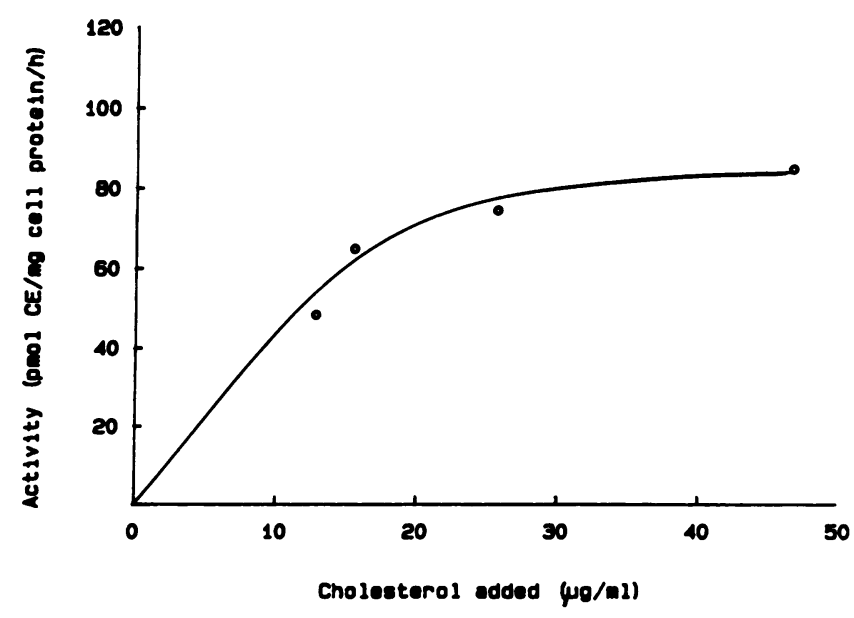

Figure 2. CE synthesis as a function of increasing amounts of platelet releasate cholesterol. Releasate was prepared and cholesterol synthetic activity was measured as described in Methods. platelet lysis or from early specific activation of the platelets. Releasates were prepared as described with the incubation of platelets and collagen terminated at $5 \mathrm{~min}$ instead of the usual incubation time of $60-90 \mathrm{~min}$. Using this 5-min releasate there was no significant difference in the either the total levels of $C E$ formed or in the CE formed per microgram of cholesterol added when compared with 60 -min releasate. There was, however, approximately fourfold more cholesterol in the 60-min releasate $\left(\sim 6.5 \mu \mathrm{g} / 10^{9}\right.$ platelets) than in the 5 -min releasate $\left(\sim 1.5 \mu \mathrm{g} / 10^{9}\right.$ platelets).

In addition, the cytoplasmic enzyme marker lactate dehydrogenase (LDH) was measured in supernatants of sedimented platelets subjected to two cycles of freeze thawing to induce cell lysis and compared with the LDH concentration present in releasate prepared in the usual fashion. The $\mathrm{LDH}$ level was undetectable in our releasate preparations, while cell lysis released an LDH level of $469 \mathrm{U} /$ liter in the freeze-thawed platelet supernatant. Taken together, these data suggest that specific platelet activation, not nonspecific lysis, is responsible for release of the form of cholesterol that is esterified by the U937 cells in our experiments, and that this cholesterol is released within minutes after activation.

Correlation among plasma cholesterol, platelet cholesterol, and CE formation by U-937 cells. Platelets were obtained from normocholesterolemic $(n=14)$ and hypercholesterolemic ( $n$ $=10$ ) individuals, activated with collagen, and tested as sources of cholesterol for esterification by U-937 cells. There were no differences between normocholesterolemic and hypercholesterolemic subjects with respect to body surface area or platelet counts. The total plasma cholesterol levels averaged $195 \pm 9$ and $432 \pm 405 \mathrm{mg} / \mathrm{dl}$, respectively.

Since platelet cholesterol content increases with increasing plasma cholesterol but over a much more limited range (43), platelet cholesterol content was measured after lipid extraction with hexane-isopropanol, as well, in these individuals. Table V lists the relationship among the plasma cholesterol concentration, platelet cholesterol content, and the ability of platelets from these subjects to stimulate CE formation by U-937 cells. The data demonstrate that increasing plasma cholesterol concentration is positively correlated with the ability of the activated platelets to promote $\mathrm{CE}$ formation by $\mathrm{U}-937$ cells in this lipoprotein-free in vitro cell system. While these results are not meant to imply that the clinical correlation between hypercho-

Table V. Relationship among Plasma Cholesterol, Platelet Cholesterol, and Platelet-dependent CE Formation by U-937 Cells

\begin{tabular}{|c|c|c|c|}
\hline$n$ & $\begin{array}{l}\text { Total plasma } \\
\text { cholesterol }\end{array}$ & Platelet cholesterol & Total CE formed \\
\hline & $m g / d l$ & $\mathrm{nmol} / 10^{8}$ platelets & $\begin{array}{l}\text { pmol } C E / m g \\
\text { protein/h }\end{array}$ \\
\hline 14 & $195 \pm 9$ & $28 \pm 1$ & $72 \pm 43$ \\
\hline 6 & $307 \pm 6$ & $32 \pm 1$ & $108 \pm 44$ \\
\hline 3 & $345 \pm 21$ & $34 \pm 1$ & $135 \pm 67$ \\
\hline 1 & 1715 & 37 & 250 \\
\hline
\end{tabular}

Plasma cholesterol, platelet cholesterol, and CE formation were determined as described in Methods and as outlined in the legends to Tables I and II. Each value represents the average \pm standard deviation of the indicated number of patients tested in each group. 
lesterolemia and atherosclerosis is a direct result of this phenomenon, they do suggest that the mechanism of platelet-derived cholesterol accumulation in U937 cells shows a dependence upon the lipid milieu in which the platelets exist. The incremental increases in total platelet cholesterol content vary to a much smaller degree than the plasma cholesterol, in agreement with the work of Shattil and co-workers (43).

\section{Discussion}

The data presented here support the view that activated human platelets may serve as potent donors of cholesterol for CE formation by the human monocytic cell, U-937. Platelets themselves are rich in unesterified cholesterol $(28,44)$, cannot synthesize cholesterol de novo (44-47), and cannot esterify cholesterol (44). While several groups have reported that platelets bind LDL (48-51), platelets do not internalize lipoproteins, degrade apoproteins (49-52), nor incorporate CE from normal lipoproteins (53). In addition, de novo cholesterol synthesis did not contribute to CE formation in this system as evidenced by lack of inhibition of CE formation by U-937 cells in the presence of lovastatin, and by the lack of conversion of $\left[{ }^{14} \mathrm{C}\right]$ acetate to cholesterol. Thus, it appears that in this system the platelet serves to provide free cholesterol to the U-937 cell for esterification.

The U937 cell was used in these experiments for several reasons. As we have noted, the in vivo mechanisms responsible for foam cell formation are not well defined. Investigators have implicated native LDL (11), chemically modified LDL (5-9), and extracellular matrix-induced alterations in the LDL-macrophage interaction (10) as possible contributors to the in vivo mechanism for foam cell formation. However, neither the receptor pathway responsible for cholesterol uptake nor the final form of cholesterol that the macrophage recognizes has been identified. We have chosen a cell that expresses only the classic LDL receptor as an initial model in which to explore the possibility that platelets may provide cholesterol in a form recognized by macrophages. The platelet is a point source of thromboxane and therefore potentially of malondialdehyde. In addition to being a simpler system than cells expressing both classic and scavenger receptors, the U-937 cell obviates concerns about malondialdehyde-modified lipoprotein interactions as a potential explanation for $\mathrm{CE}$ formation through scavenger receptor mechanisms.

The form in which cholesterol is transferred to the U-937 cell from the platelet is unclear from these experiments. In the simplest case, one could argue that since platelets bind LDL (48-52), this surface-bound lipoprotein might be the cholesterol source in these experiments, despite repeated washings of the platelets with buffer before incubation with monocytes. However, using the value of Curtiss and Plow (51) of $8 \mu \mathrm{g}$ of LDL cholesterol bound per $10^{9}$ activated platelets at saturation, only $2.7 \mu \mathrm{g}$ of cholesterol would be provided at most by platelet surface-associated LDL in this assay, a value that is only $0.7 \%$ of the LDL cholesterol added $(382 \mu \mathrm{g})$ in the lipoprotein controls (Table I) and, therefore, far less than that required to promote $\mathrm{CE}$ synthesis in this system.

That a soluble 1,000-g supernatant of the activated platelets was also active in this assay and, per microgram of cholesterol, about as active as activated platelets themselves, argues that in the process of platelet activation and aggregation a cholesterol-rich substance is generated in the releasate. In addition, the form in which this cholesterol is released must readily facilitate its uptake by U-937 cells. Sandberg and colleagues (30) have isolated and partially characterized such an activated platelet releasate in their studies of platelet Factor 3 and have found that it contains membranous particles of $70-170 \mathrm{~nm}$ in diameter composed of $40 \%$ protein, $42 \%$ phospholipid, $13 \%$ unesterified cholesterol, and 5\% triacylglycerols. It may be that such platelet-derived "lipo-protein" particles promote cholesterol uptake and esterification by U-937 cells.

Kruth (27) has recently reported that activated rat platelets induce CE droplet accumulation by cultured rat aortic smooth muscle cells using a qualitative histologic method. He also isolated a 10,000-g supernatant from thrombin-activated platelets and demonstrated that this fraction of the releasate contains the active, cholesterol-containing substance necessary for ester formation by smooth muscle cells. Our data support and extend these findings and suggest that the phenomenon described here for human cells may be relevant for the process of cholesterol accumulation in both the macrophages and smooth muscle cells of evolving atheroma.

The teleologic importance of a platelet-mediated mechanism of cholesterol delivery is difficult to determine. One possible explanation might be that in the ongoing participation of platelet adhesion, activation, and aggregation at sites of endovascular injury, the cholesterol released from these blood cells would function in the reparative process as a sterol source for membrane synthesis and repair. In atherogenesis, this normal reparative process achieves pathophysiologic dimensions, depositing cholesterol at sites of injury and providing a cholesterol source for developing foam cells. Current evidence has identified the development of foam cells and fatty streaks under intact endothelium $(25,26)$. Our data raise the possibility of an interaction between activated platelets and macrophages before foam cell development, perhaps in the circulation, or, of course, in later stages of plaque development. Such an interaction could occur either at deendothelialized sites or despite the presence of what appears to be morphologically normal, intact endothelium (23). This latter possibility might imply biochemical perturbations in endothelial integrity or a more continuous, dynamic interaction between the macrophage and platelet during the complex events of the atherosclerotic process.

\section{Acknowledgments}

The authors wish to thank Dr. Ian Rous, Dr. Frank Sacks, Dr. Michael Gimbrone, and Dr. Jerry Majeau for providing the U-937 cells and for suggestions and assistance in certain of the lipid analyses. We thank Dr. Robert Lopez for his assistance with the assay for LDH. We also wish to thank Ms. Jane Freedman for excellent technical assistance.

Dr. Mendelsohn is the recipient of a Young Investigators Award from the American Federation of Clinical Research for portions of this work. Dr. Loscalzo is the recipient of a Clinician-Scientist Award from the American Heart Association. This work was supported in part by a Grant-in-Aid from the American Heart Association, Massachusetts Affiliate.

\section{References}

1. Goldstein, J. L., and M. S. Brown. 1977. The low-density lipoprotein pathway and its relation to atherosclerosis. Annu. Rev. Biochem. 46:897-930. 
2. Goldstein, J. L., Y. K. Ho, S. K. Basu, and M. S. Brown. 1979. Binding site on macrophages that mediates uptake and degradation of acetylated low-density lipoprotein, producing massive cholesterol deposition. Proc. Natl. Acad. Sci. USA. 76:333-337.

3. Fogelman, A. M., I. Schechter, J. Seager, M. Hokom, J. S. Child, and P. A. Edwards. 1980. Malondialdehyde alteration of low-density lipoproteins leads to cholesteryl ester accumulation in human monocyte-macrophages. Proc. Natl. Acad. Sci. USA. 77:2214-2218.

4. Traber, M. G., and H. J. Kayden. 1980. Low-density lipoprotein receptor activity in human monocyte-derived macrophages and its relation to atheromatous lesions. Proc. Natl. Acad. Sci. USA. 77:5466-5470.

5. Knight, B. L., and A. K. Soutar. 1982. Degradation by cultured fibroblasts and macrophages of unmodified 1,2-cyclohexanedionemodified low-density lipoprotein from normal and homozygous familial hypercholesterolemic subjects. Biochem. J. 202:145-152.

6. Mahley, R. W., T. L. Innerarity, K. H. Weisgraber, and S. Y. Oh. 1979. Altered metabolism (in vivo and in vitro) of plasma lipoproteins after selective chemical modification of lysine residues of the apoproteins. J. Clin. Invest. 64:743-750.

7. Raymond, T. L., S. A. Reynolds, and J. A. Swanson. 1985. Lipoproteins of the extravascular space: enhanced macrophage degradation of low density lipoproteins from interstitial inflammatory fluid. J. Lipid Res. 26:1356-1362.

8. Parthasarthy, S., D. J. Printz, D. Boyd, L. Joy, and D. Steinberg. 1986. Macrophage oxidation of low density lipoprotein generates a modified form recognized by the scavenger receptor. Arteriosclerosis. 6:505-510.

9. Lopes-Virella, M., R. L. Klein, T. Lyons, H. C. Stevenson, and J. L. Witztum. 1985. In vitro glycosylated LDL enhances cholesteryl ester synthesis in human monocyte-derived macrophages. Arteriosclerosis. 5:507A

10. Falcone, D. J., N. Mated, H. Shio, C. R. Minick, and S. D. Fowler. 1984. Lipoprotein-heparin-fibrinonectin-denatured collagen complexes enhance cholesterol ester accumulation in macrophages. $J$. Cell Biol. 99:1266-1274.

11. Tabas, I., D. A. Weiland, and A. R. Tall. 1985. Unmodified low density lipoprotein causes cholesterol ester accumulation in $\mathrm{J} 774$ macrophages. Proc. Natl. Acad. Sci. USA. 82:416-420.

12. Wang-Iverson, P., H. N. Ginsberg, L. A. Peteanu, Ngoc-Anh Le, and W. V. Brown. 1985. Apo-E mediated uptake and degradation of normal very low density lipoproteins by human monocyte/macrophages: a saturable pathway distinct from the LDL receptor. Biochem. Biophys. Res. Commun. 126:578-586.

13. Koo, C., M. E. Wernette-Hammond, and T. L. Innerarity. 1986. Uptake of canine $\beta$-very low density lipoproteins by mouse peritoneal macrophages is mediated by a low density lipoprotein receptor. J. Biol. Chem. 261:11194-11201.

14. Ellsworth, J. L., F. B. Kraemer, and A. D. Cooper. 1987. Transport of $\beta$-very low density lipoproteins and chylomicron remnants by macrophages is mediated by the low density lipoprotein receptor pathway. J. Biol. Chem. 262:2316-2325.

15. Bjorkerud, S., and G. Bondjers. 1973. Arterial repair and atherosclerosis after mechanical injury. Atherosclerosis. 18:235-255.

16. Moore, S. 1973. Thromboatherosclerosis in normolipemic rabbits. Lab. Invest. 29:478-487.

17. Friedman, R. J., S. Moore, and D. P. Singal. 1975. Repeated endothelial injury and induction of atherosclerosis in normolipemic rabbits by human serum. Lab. Invest. 32:404-415.

18. Moore, S., and I. O. Ihnatowycz. 1977. Vessel injury and atherosclerosis. Adv. Med. Exp. Biol. 102:145-163.

19. McKully, K. S., and R. B. Wilson. 1983. Homocysteine theory of arteriosclerosis. Atherosclerosis. 22:215-227.

20. Harker, L. A., R. Ross, S. J. Slichter, and C. R. Scott. 1976. Homocystine-induced arteriosclerosis. J. Clin. Invest. 58:731-741.

21. Boers, G. H. J., A. G. H. Sonals, F. J. M. Trijbels, B. Fowler, J. A. J. M. Bakkeren, H. C. Schoonderwaldt, W. J. Kleijer, and P. W. C. Kloppenborg. 1985. Heterozygosity for homocystinuria in premature peripheral and cerebral occlusive arterial disease. $N$. Engl. J. Med. 313:709-715.

22. Murphy-Chutorian, D. R., M. P. Wexman, A. J. Grieco, J. A. Heininger, E. Glassman, G. E. Gaull, S. K. C. Ng, F. Feit, K Wexman, and A. C. Fox. 1985. Methionine intolerance: a possible risk factor for coronary artery disease. J. Am. Coll. Cardiol. 6:725-730.

23. Marshall, M. 1986. Ultrastructural findings on platelet deposition in initial atherogenesis. Wien. Klin. Wochenschr. 98:212-214.

24. Ross, R., J. Glomset, B. Kariya, and L. Harker. 1974. A platelet-dependent serum factor that stimulates the proliferation of arterial smooth muscle cells in vitro. Proc. Natl. Acad. Sci. USA. 71:12071210.

25. Faggiotto, A., R. Ross, and L. Harker. 1984. Studies of hypercholesterolemia in the nonhuman primate. I. Changes that lead to fatty streak formation. Arteriosclerosis. 4:323-340.

26. Faggiotto, A., and R. Ross. 1984. Studies of hypercholesterolemia in the nonhuman primate. II. Fatty streak conversion to fibrous plaque. Arteriosclerosis. 4:341-356.

27. Kruth, H. S. 1985. Platelet-mediated cholesterol accumulation in cultured aortic smooth muscle cells. Science (Wash. DC). 227:1243-1245.

28. Shattil, S. J., R. Anaya-Galinda, K. Bennett, R. W. Colman and R. A. Cooper. 1975. Platelet hyperreactivity induced by cholesterol incorporation. J. Clin. Invest. 55:636-643.

29. Friedman, R. J., M. B. Stemerman, B. Wenz, S. Moore, J. Gauldie, M. Gent, M. L. Tiell, and T. H. Spaet. 1977. The effect of thrombocytopenia on experimental arteriosclerotic lesion formation in rabbits. J. Clin. Invest. 60:1191-1201.

30. Sandberg, H., L.-O. Andersson, and S. Hoaglund. 1982. Isolation and characterization of lipo-protein particles containing platelet factor 3 released from platelets. Biochem. J. 203:303-311.

31. Sundstrom, C., and K. Nilsson. 1976. Establishment and characterization of human histiocytic lymphoma cell-line (U-937). Int. J. Cancer. 7:565-577.

32. Via, D. P., A. L. Plant, I. F. Craig, A. M. Gotto, Jr., and L. C. Smith. 1985. Metabolism of normal and modified low-density lipoprotein by macrophage cell lines of murine and human origin. Biochim. Biophys. Acta. 833:417-428.

33. Havel, R. M., H. A. Eder, and J. H. Bragdon. 1955. The distribution and chemical composition of ultracentrifugally separated lipoproteins in human serum. J. Clin. Invest. 34:1345-1353.

34. Brown, M. S., J. L. Goldstein, M. Krieger, Y. K. Ho, and R. G. W. Anderson. 1979. Reversible accumulation of cholesteryl esters in macrophages incubated with acetylated lipoproteins. J. Cell Biol. 82:597-613.

35. Goldstein, J. L., S. E. Dana, and M. S. Brown. 1974. Esterification of low-density lipoprotein cholesterol in human fibroblasts and its absence in homozygous familial hypercholesterolemia. Proc. Natl. Acad. Sci. USA. 71:4288-4292.

36. Hara, A., and N. S. Radin. 1978. Lipid extraction of tissues with a low-toxicity solvent. Anal. Biochem. 90:420-426.

37. Heider, J. G., and R. L. Boyett. 1978. The picomole determination of free and total cholesterol in cells in culture. J. Lipid Res. 19:514-518.

38. Gamble, W., M. Vaughan, H. S. Kruth, and J. Avignan. 1978. Procedure for determination of free and total cholesterol in micro- or nanogram amounts suitable for studies with cultured cells. J. Lipid Res. 19:1068-1070.

39. Rudel, L. L., and M. D. Morris. 1973. Determination of cholesterol by o-phthalaldehyde. J. Lipid Res. 14:364-366.

40. Lowry, O. H., N. R. Rosebrough, A. L. Farr, and R. Randall. 1951. Protein measurement with the Folin reagent. J. Biol. Chem. 193:265-275.

41. Kapuscinski, J., and B. Skoczylas. 1977. Simple and rapid fluorimetric method for DNA microassay. Anal. Biochem. 83:252257.

42. Wacker, W. E. C., D. D. Ulmer, and B. L. Vallee. 1956. Metalloenzymes and myocardial infarction: malic and lactic dehydrogenase 
activities and zinc concentrations in serum. N. Engl. J. Med. 255:449-456.

43. Shattil, S. J., J. S. Bennett, R. W. Colman, and R. A. Cooper. 1977. Abnormalities of cholesterol-phospholipid composition in platelets and low-density lipoproteins of human hyperbetalipoproteinemia. J. Lab. Clin. Med. 80:341-353.

44. Schick, B. P., P. K. Schick, and P. R. Chase. 1981. Lipid composition of guinea pig platelets and megakaryocytes. Biochim. Biophys. Acta. 663:239-248.

45. Deykin, D., and R. K. Desser. 1968. The incorporation of acetate and palmitate into lipids by human platelets. J. Clin. Invest. 47:1590-1602.

46. Derksen, A., M. M. Meguid, and P. Cohen. 1976. Non-human primate platelets and arterial tissue cannot convert preformed $\left[{ }^{14} \mathrm{C}\right]-$ lanosterol into $\left[{ }^{14} \mathrm{C}\right]$-cholesterol in vivo. Biochem. J. 158:157-159.

47. Derksen, A., and P. Cohen. 1975. Extensive incorporation of $2-\left[{ }^{14} \mathrm{C}\right]$ mevalonic acid into cholesterol precursor by human platelets in vitro. J. Biol. Chem. 248:7396-7403.
48. Aviram, M., J. C. Brook, A. M. Lees, and R. M. Lees. 1981. Low-density liproprotein binding to human platelets: role of charge and of specific amino acids. Biochem. Biophys. Res. Commun. 99:308-318.

49. Koller, E., F. Koller, and W. Doleschel. 1982. Specific binding site on human blood platelets for plasma lipoproteins. Hoppe-Seyler's Z. Physiol. Chem. 363:395-405.

50. Aviram, M., and J. G. Brook. 1983. Platelet interactions with high and low-density lipoproteins. Atherosclerosis. 46:259-268.

51. Curtiss, L. K., and E. F. Plow. 1984. Interaction of plasma lipoproteins with human platelets. Blood. 64:365-374.

52. Masurov, A. V., S. N. Preobrazhensky, V. L. Leytin, V. S. Repin, and V. N. Smirnov. 1982. Study of low-density lipoprotein interactions with platelets by flow cytofluorimetry. FEBS (Fed. Eur. Biochem. Soc.) Lett. 137:319-324.

53. Schick, B. P., and P. K. Schick. 1985. Cholesterol exchange in platelets, erythrocytes, and megakaryocytes. Biochim. Biophys. Acta. 833:281-290. 